\title{
Misconception on the Implementation of Diversion System Within Child Criminal Justice System in Indonesia
}

\author{
Nikmah Rosidah ${ }^{1}$, Chaidir Ali $^{2}$ \\ \{nikmahrosidah@yahoo.com ${ }^{1}$, chaidirali678@gmail.com²\} \\ Faculty of Law University of Lampung, Indonesia ${ }^{12}$
}

\begin{abstract}
Based on Article 7 of Law Number 11 of 2012 concerning Child Criminal Justice System (CCJS Law) which stipulates that at the level of investigation, prosecution and examination of children's cases in the district court must be pursued for diversion and the crime that is punishable by imprisonment under seven years and not a residiv crime. Diversion itself is intended to ensure that child crime cases can be settled out of court. However, in practice of diversion often cannot work well since the stakeholder relating to such issue also legal enforcer didn't understand the essence of the diversion. Using the juridic-normative research method with case study approach, this study found that the application of the diversion often recognized to be similar as giving compensation to the victim of child crime, though those conception are greatly different to each other. Thus, it can be concluded the urge of knowledge improvement about the diversion and the need for public education through legal counseling to understand the intention of the diversion itself. Ultimately, the diversion is expected to be optimally applied.
\end{abstract}

Keywords: Implementation; Diversion; CCJS

\section{Introduction}

The emergence of the child criminal justice system in Indonesia since 2012, was not implemented merely without any underlying factors. The formation of child criminal court in Indonesia based on the existence of a constitutional mandate, mainly in the provisions of article 28B paragraph (2) of the 1945 Constitution of the Republic of Indonesia Unitary State which determined that:

"Every child shall have the right to live, grow and to develop and shall have the right to protection from violence and discrimination".

That all children who are in Indonesia, have the same right to live, grow and develop and are protected from violence and discrimination. So that it can be underlined in here is that the Republic of Indonesia at least recognizes and is obliged to protect the five elements of children's rights. One of the elements in fulfilling children's rights is protection against violence and discrimination. The relations between recognition of the Unitary Republic of Indonesia and its obligation to fulfill that right. Impact on the steps of the government of the Republic of Indonesia to establish a child criminal court that specifically handles criminal cases involving children as the perpetrators of the crime. The importance of the existence of 
this institution because it is the main means of fulfilling the rights of children protected through the constitution.

Of course it is necessary to understand that not every child can benefit from being born into a whole and loving family. Not a few children who do not experience conditions as fortunate as this, not a few of the children who even have to live without proper education or even without family and fall in street life. Such conditions often result in children being involved in juvenile delinquency, which sometimes even leads to criminal offenses. The state, however, must be able to take responsibility in this matter. Because of course a child who has a criminal record will face a long road ahead of his life in society in the context of facing discrimination. Discrimination arises due to the label attached to a child who has been sentenced as a criminal of a criminal offense.

The necessity for the protection of children's rights to avoid discriminatory attitudes is the fundamental foundation in the formation of child criminal court in Indonesia. In addition, the formation of child criminal court is also equipped with a strategy to resolve criminal cases involving children as crime makers to be resolved outside the court. This system is referred as diversion, but due to the unpreparedness of the society and law enforcers. As a result, the diversion system so far can be said to be less than optimal. This paper will perform discussion on the optimization or shortcomings in the application of the diversion system.

\section{Discussion}

\subsection{The Philosophical Foundation Of The Diversion System}

The diversion system is an effort to shift from a retributive justice system adopted by criminal justice in Indonesia to a restorative justice system. The difference between the two is that the retributive justice system provides punishment to create peace in the community and a deterrent effect on the perpetrators of crime. Unlike this condition, the restorative justice system seeks to produce a level of legal awareness as well as inculcation of guilt and a desire to be responsible of the mistake that were committed to the perpetrators of crime. Compared to a retributive justice system that merely emphasizes punishment, a restorative justice system is considered to be more guaranteeing the continued growth and development of children as responsible individuals and can be used as a means to instill a sense of responsibility and awareness of the mistakes that have been made. Restorative justice systems emerge as a strong foundation in overcoming the problem of children who become crime makers and the interests to fulfill the constitutional rights of children to be able to grow up and protected from violence and discrimination.

This makes the restorative justice system as the foundation of child criminal justice system in Indonesia with its manifestation in the form of a diversion system. However, not all children who are involved with crime as perpetrators can enjoy the diversion system facilities in child criminal court. Restrictions are still placed on children who can enjoy these facilities, such restrictions are carried out because crime is not a stand-alone phenomenon. But a humanitarian problem or social problem that continues to develop as a complex phenomenon and has a relations with other social structures. Restorative justice system that emphasizes restoration efforts for victims of crime and perpetrators of crime. Equipped with restrictions on who the perpetrators of crime who can receive this diversion facility. This restriction is in the form of the application of the diversion system only for children who are mentally, psychologically and intellectually immature to judge that the his/her act is a crime. Law 
Number 11 Year 2012 concretely stipulates that the so-called children are those who are 12 years old and have not yet reached the age of 18 years.

Other restrictions also arise based on the type of crime committed by the child. The diversion system can be applied as long as the crime committed is a crime that is punishable by imprisonment under 7 years and is not a recidivist/crime repetition by the child. So this diversion system is really aimed for the children's who were commit crimes for the first time and crimes committed was not classified as serious crimes or have a severe impact on social structure. In his opinion R.Wiyono pointed out that if there is a criminal offense in contrary to the above two conditions in which it would cause logical consequences of child crime to be not obliged to diversion. Thus, the notion of "not obliged to be diverted" has a meaning that is not imperative or facultative. This means for a crime of a child who is punishable by imprisonment of more than 7 (seven) years or in the case of a child committing a criminal act. It can be attempted to divert.

However, according to M Nasir Djamil, former chairman of the House of Representatives' Committee for Child Criminal Justice Commission III, said that the aforementioned matters may have logical consequences for the actions of children who is dealing with the law to be not required to be diverted. Caused if the child is threatened with imprisonment more than 7 (seven) years. Hence, the crime is a serious criminal offense or if he / she commits a repetition of a crime. Thus, it can be concluded that the purpose of diversion. That is to instill a sense of responsibility to the child not to repeat a similar criminal act is not achieved. Thus, resulting in the logical consequences of the diversionary effort against it is not mandatory.

\subsection{Diversion System Implementation Failure}

Although the diversion effort has been designed in such way, however, at the level of its implementation, not infrequently these diversion efforts experienced rejection by the victim or the victim's family. This can be seen from one example of a case that occurred in the jurisdiction of the Kotabumi District Attorney, where there is a suspect with the initials HS Bin Y who commits a criminal act of fencing as stipulated in article 480 of the Criminal Code. The North Lampung Police Investigator who handles the case carried out the legal process of investigation based on Police Report Number: LP/930/XI/2014/POLDA LPG/RES LU, Investigation Order Number: SP. Sidik/659/XI/2013/Reskrim dated 26 November 2013, and Notice of Commencement of Investigation Number: SPDP/197/XI/2014/Reskrim.

The State Prosecutors of Kotabumi through the Public Prosecutor in this case conduct a diversion effort as outlined in the Minutes of Diversity Number: 02/N.8.13/Ep.1/12/2014. The point of diversion is the perpetrator to compensate the victim of Rp. 2,000,000, the perpetrator promised not to repeat his actions and if the agreement is not met then the legal process will continue. However, the victim and the victim's family subsequently refused this diversion attempt. Due to the intention of made HS to be processed in court and properly punished as regulated in Criminal Code. Because of the criminal acts committed by HS has been disturbing local residents. Thus, the victim and the victim's family want HS to be sentenced to prison in accordance with his actions.

Although in the end, the Kotabumi District Court through Verdict Number: 11/Pid.SusAnak/2014/PN.Kbu stipulates the process of examination of the child and ordered the prosecutor to remove the child from the prisons of Kotabumi Children's Prison. Because the Judge considers that the diversion at the Court's examination level has been successful. The above case sample show that conceptually, diversion does have a noble purpose. However, at the time of its implementation, people tend to refuse to implement diversion efforts primarily by victims or families of victims. 
This failure can be understood due to ignorance by the victim and the victim's family regarding the different characteristics of general criminal court and child criminal court. Because, the diversion was made in the settlement of the case, indicating that the child who made the crime had met the criteria for the child who committed the crime in order to implement the diversion system in his case. This means that according to the assessment of investigators and public prosecutors, HS, who is a criminal offense, had his first time committing the act and the crime is a minor crime. For the sake of protecting HS from violence in the form of taking his freedom through imprisonment. Thus, diversionary efforts were made to resolve the case without criminal punishment.

Unfortunately, the victim and victim's families are closely related to the retributive justice system that exists in general justice in Indonesia so far. The victim and the victim's family encourage the court to remain investigated the case and even want him to be punished according to the provisions in general criminal justice. The doctrine of the retributive justice system needs to be eradicated in society by promoting the rights of children as an excuse for the importance of the diversion system. In addition, other failures was illustrated through the cases sample that failed to implement the diversionary effort in Lampung. Occurs because there is a compensation component required by the victim for diversion to be implemented. In author opinion such request was an abused of the diversion system by the victim to reap materialistic benefits. This is not in line with the philosophical objectives of the diversion system which requires diversion efforts to be carried out in order to restore the state of the perpetrators of crime and victims of crime.

Compensation given could be said was conducted to restore the situation of the victim, but it was not give the same thing to the perpetrators of crimes which incidentally are children. Let's say that the compensation given to compensate for the loss suffered by the victim. But which party pays the compensation, the child who committed the crime or just the other party. If the imposition of compensation is justified on the grounds that the offender feels deterrent, then it can be criticized in this way.

The diversionary effort aims to instill a sense of responsibility and awareness of wrongfully act directly to the child offender. The request for compensation is less animating, it would be better if the victim or the victim's family can simply want an apology from the child of the perpetrator directly as a condition for diversion rather than requesting compensation.

Inaccuracies that occur in the implementation of the diversion system occur due to the lack of public understanding of children's rights. Mainly in the context as specified in article 28B paragraph (2) of the Constitution of the Unitary Republic of Indonesia in 1945. That children have the right to live, grow and develop and get protection from violence and discrimination. The emergence of child criminal court and the diversion system that was born from its womb are solely intended as a means of helping children who are trapped in criminal behavior to be able to return being a good and responsible person. Not encourage him to be punished and labeled as a criminal all his life.

\section{Conclusion}

The successful fulfillment of the constitutional rights of children as stipulated in article 28B paragraph (2) of the 1945 Constitution of the Unitary Republic of Indonesia, is pursued through the establishment of child criminal court. child criminal court emerged with the consequence of shifting the understanding of the retributive justice system that has flourished in general court in Indonesia, to shifting into a restorative justice system that wants a balanced restoration of perpetrators and crime victims. 
Unfortunately, the strong doctrine of the retributive justice system makes victims affected by child crime be reluctant to use methods that are outside of punishment. While the diversion system that was born from the restorative justice system of child criminal justice system does not want that. The long road that needs to be taken is to change the understanding of the community to be able to voluntarily accept the ways presented by the diversion system through the promotion of children's rights, that every child has the same opportunity to develop. The internalization process is expected to bring changes in the community paradigm in responding to criminal acts committed by children by not discriminating against child offenders. But opening their hands widely to help the child realize mistakes and instill a sense of responsibility not to repeat the mistakes. The law enforcers who strive for this diversion system also need to be present as third parties who oversee the implementation of the diversion effort so that it is not misused into a mere profit-making event.

\section{References}

[1] Maroni. (2016). Pengantar Politik Hukum Pidana. Bandar Lampung: Aura.

[2] Djamil, M. Nasir. (2013). Anak Bukan untuk Dihukum. Jakarta: Sinar Grafika.

[3] Wiyono, R. (2016). Sistem Peradilan Pidana Anak. Jakarta: Sinar Grafika.

[4] Law No. 11 of 2012 concerning Child Criminal Justice System. 